Halberstadt, A.R.W., Kowalewski, D.E., DeConto, R.M. 2022, Reconciling persistent sub-zero temperatures in the McMurdo Dry Valleys, Antarctica, with Neogene dynamic marine ice-sheet fluctuations: Geology, https://doi.org/10.1130/G49664.1

\title{
SUPPLEMENTAL MATERIAL
}

\section{S1. Numerical climate and ice-sheet modeling}

S2. Impact of prevailing wind patterns on MDVs climate

S3. Temperature dependence on regional ice sheet geometry

S4. Compilation of MDVs landforms and sedimentary deposits

S5. Snow accumulation in model simulations

Fig. S1: Landscape evolution reconstructed by Paxman et al. (2019) over the study region Fig. S2: Model validation based on meteorological observations

Fig. S3: Modeled MDVs climatology under $460 \mathrm{ppm} \mathrm{CO}_{2}$

Fig. S4: Impact of ice-sheet geometry on MDVs temperature patterns

Fig. S5: Location of dated landforms and sedimentary deposits with respect to modeled cold zones

Table S1: Compilation of UFZ landforms and sedimentary deposits across the MDVs

Fig. S6: Seasonal snow depths across the MDVs

\section{S1. Numerical climate and ice-sheet modeling}

\section{Model initialization}

Our simulations are initiated from equilibrated ice sheet and climate model output from (Halberstadt et al., 2021), performed under 280 and 460 ppm $\mathrm{CO}_{2}$ boundary conditions with no topographic alteration (Fig. 2a). Halberstadt et al. (2021) asynchronously coupled an ice-sheet model (10 km resolution; Pollard and DeConto, 2012) with a global climate model $\left(2^{\circ}\right.$ surface resolution and T31 atmosphere; GENESIS; Alder et al., 2011) downscaled to a $60 \mathrm{~km}$ resolution regional climate model over Antarctica (RegCM3; Pal et al., 2007) and further downscaled at a $10 \mathrm{~km}$ resolution over the McMurdo Dry Valleys (MDVs). Warm interglacial climates are represented by an astronomical configuration favorable for Antarctic deglaciation (warm austral summer) and an additional Southern Ocean heat flux (DeConto et al., 2012).

Although Halberstadt et al. (2021) focused on the mid-Miocene, we extend their approach to the late Miocene through Plio-Pleistocene by selecting appropriate model boundary conditions; model $\mathrm{CO}_{2}$ concentrations (280 and $460 \mathrm{ppm}$ ) are consistent with the geologic reconstructions across the Miocene and Plio-Pleistocene (e.g., Pagani et al., 2010; Seki et al., 2010; Martínez-Botí et al., 2015; Badger et al., 2019; Stoll et al., 2019; Rae et al., 2021). We further represent post-mid-Miocene interglacial conditions by imposing a semi-desert land use type in the regional climate model, based on hyper-arid conditions implied by terrestrial landscapes (Marchant et al., 1996; Marchant and Head, 2007) 


\section{Topographic boundary conditions for model simulations}

We use a 14 Ma Antarctic topographic reconstruction (Paxman et al., 2019) that places the Transantarctic Mountains (TAM) at near-modern elevation (see below). Because East Antarctic topography is roughly similar to present-day over our model domain (Paxman et al., 2019), model results can be considered representative of mid-Miocene-to-present-day conditions because the $14 \mathrm{Ma}$ topography within our modeled region experienced relatively minimal modification after the mid-Miocene (Fig. S1). Paxman et al. (2019) reconstruct the majority of erosion and landscape formation across East Antarctica prior to $14 \mathrm{Ma}$, including valley incision of the outlet glaciers bisecting the TAM (although West Antarctica experienced more recent landscape modification; see Paxman et al., 2019, Figure 7).

Preserved ancient landscapes in the MDVs preclude significant glacial valley erosion during the Plio-Pleistocene, so we assume that topographic relief during past warm periods was similar to today. However, the uplift history of the TAM is still under investigation; Paxman et al. (2019) assume that the majority of TAM uplift had already occurred by $14 \mathrm{Ma}$, although other geological studies reconstruct post-mid-Miocene uplift (e.g., Webb, 1974; Miller et al., 2010; Austermann et al., 2015). Ongoing TAM uplift throughout this time period would impact our modeled distributions of persistently cold temperatures.

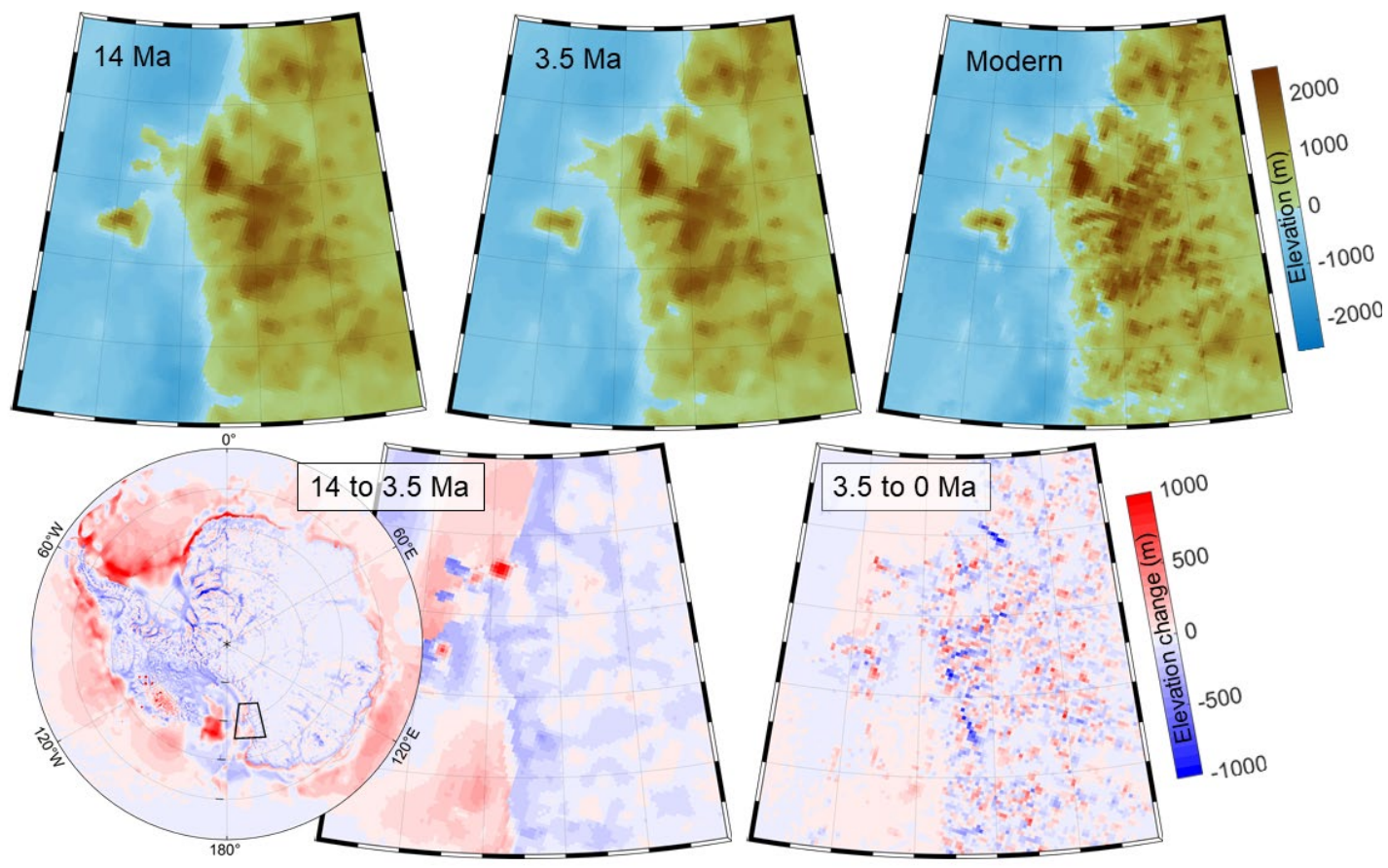

Figure S1. Landscape evolution reconstructed by Paxman et al. (2019) over the study region (same domain as in Fig. 1c). The mid-Miocene topography (14 Ma) is used in this study. Mid-Miocene, mid-Pliocene (3.5 Ma), and modern topographies are isostatically relaxed. Elevation change across East Antarctica after $14 \mathrm{Ma}$ was minimal. See Paxman et al. (2019) Fig. 6 and Fig. 7 for continent-wide topographies and elevation change plots. 


\section{Climate model validation using a present-day nested simulation}

We additionally perform a present-day simulation under modern boundary conditions, and compare model climatology to modern meteorological observations. The MDVs are characterized by high-relief valleys and peaks, with significant microclimate variability (Doran et al., 2002). We therefore conducted a present-day model experiment to assess the ability of our climate model to robustly represent temperature patterns across the topographically and climatically complex MDVs. This additional simulation used 'modern' orbital configuration, bathymetry, and other boundary conditions, with the same domain and grid resolution $(10 \mathrm{~km})$ as the paleo-warm-world simulations. The resulting climate model output successfully captures broad climatic trends across the MDVs when compared with modern high-resolution weather prediction modeling over the MDVs (Fig. 3) as well as meteorological measurements at specific locations (Fig. S2). Generally, model/data agreement is highest during the austral summer, despite smaller measured temperature variability. This is consistent with the observation that summer temperatures are more predictable (Doran et al., 2002) and less influenced by katabatic winds (Nylen et al., 2004), and supports the robustness of the summer temperatures we model during past warm periods.
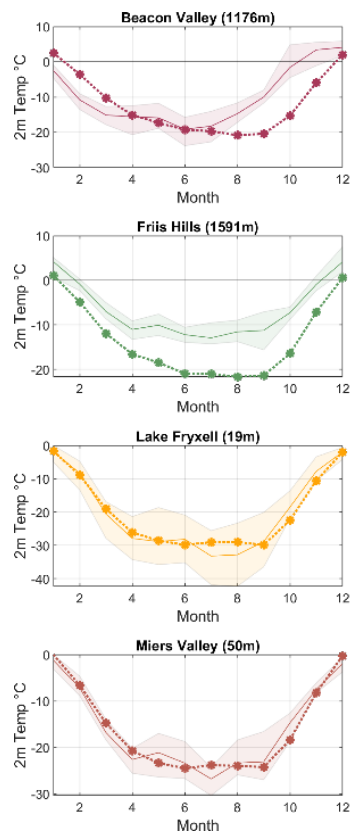
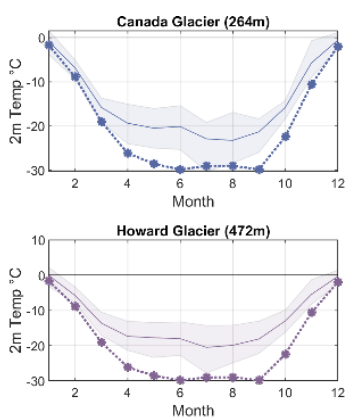

Lake Hoare $(77 \mathrm{~m})$
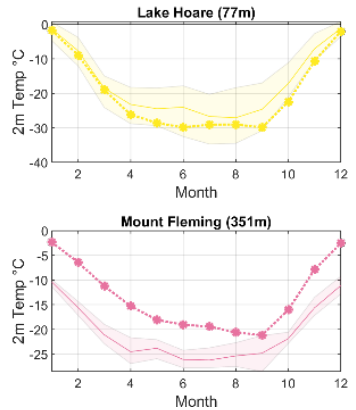
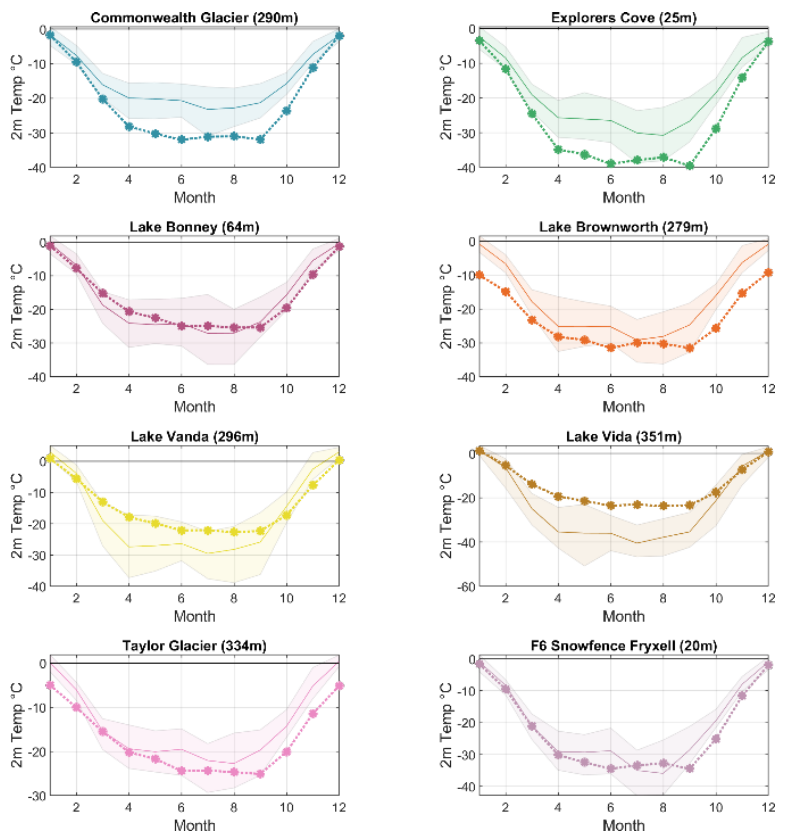

Figure S2. Model validation based on meteorological observations. Modern modeled temperature (solid circles connected by a dotted line) is compared to meteorological data from Long Term Ecological Research stations in the MDVs (averaged monthly temperature plotted as a solid line, with minimum and maximum temperatures for each month shown as a shaded range). Model climatology was averaged across a 10-year simulation, and monthly mean temperatures were queried at the location of each meteorological station. The elevation of each meteorological station is displayed next to the station name; both modeled and measured temperatures are corrected to sea level using the summer adiabatic lapse rate of $0.1^{\circ} \mathrm{C} \mathrm{km}-1$ (Doran et al., 2002) in order to appropriately compare modeled temperature within a $10-\mathrm{km}$ grid cell to a pinpoint meteorological measurement at a specific elevation. Meteorological station data were acquired by Doran and Fountain (2019a-p). 


\section{S2. Impact of prevailing wind patterns on MDVs temperatures}

Under past warm conditions, summer westerly winds carried warmth and moisture from the open marine Ross Sea onto the MDVs coast and low-elevation regions, mixing with cold and dry winds flowing off the ice sheet across high-elevation MDVs uplands (Fig. S3a). Generally similar prevailing wind patterns occur today, whereby westerly coastal winds bring warmth and moisture to lower-lying coastal regions, although complex smaller-scale climatic processes such as up-valley warming add spatial variability to this broad trend (Doran et al., 2002; Obryk et al., 2020). These large-scale prevailing winds, along with storm events, influence precipitation patterns over the MDVs (Fig. S3c): precipitation is therefore highest along the coast and lowest in the cold uplands, although our modeled precipitation rates exceed past hyper-arid conditions estimated from geomorphic landforms. Despite these intermixing winds, summer temperatures generally follow elevation contours (Fig. S3b). A linear relationship is observed between modern summer temperature and elevation (Fig. 3).
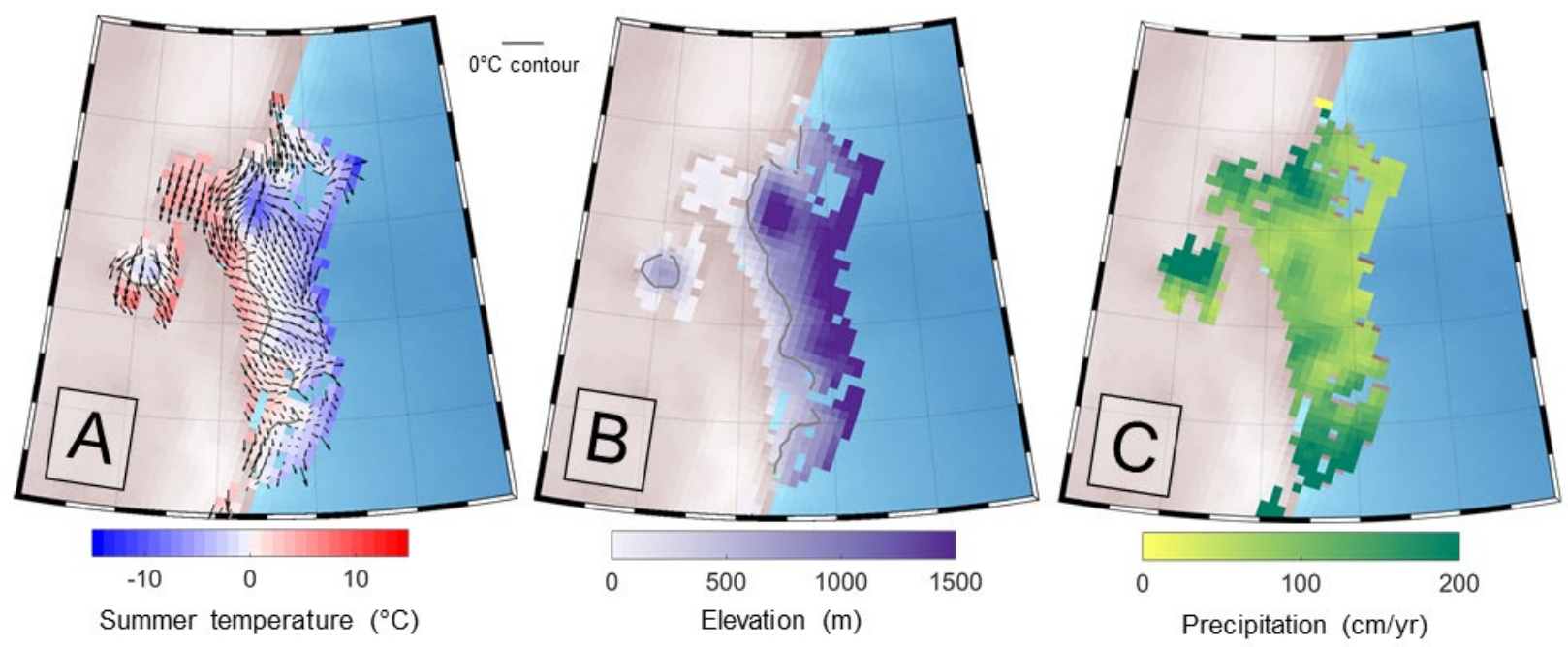

Figure S3. Modeled MDVs climatology under $460 \mathrm{ppm} \mathrm{CO}_{2}$. (A) Summer temperature and prevailing surface-level winds (grey arrows), (B) surface elevation, and (C) annually averaged precipitation.

\section{S3. Temperature dependence on regional ice sheet geometry}

We investigate whether the proximity of a nearby ice sheet produces a cooling effect on high-elevation MDVs uplands. In the high- $\mathrm{CO}_{2}$ scenario, our 690 ppm equilibrated model ensemble member simulates only a small TAM ice cap over the MDVs region, with much of Wilkes Subglacial Basin deglaciated (Fig. 2a); the imposition of modern ice-free conditions onto these original boundary conditions leaves limited ice cover across the region (Fig. S4a). With this glacial configuration, only small and sparse ice caps exist over the TAM. We perform additional model experiments to isolate the impacts of atmospheric $\mathrm{CO}_{2}$ and ice configuration by applying 460 ppm climate boundary conditions over this sparsely glaciated 690-ppm-equilibrated ice sheet configuration, and vice versa. Although slight cooling seems to occur within $\sim 10 \mathrm{~km}$ (one model grid cell) from the ice-sheet margin, we find no significant impact of ice 
configuration on temperature distribution in the MDVs at a regional scale (Fig. S4b). Under 690 $\mathrm{ppm}$, the presence of ice surrounding the MDVs seems to exert a slight cooling at high elevations, but under $460 \mathrm{ppm}$, the effect is in the opposite direction (the simulation using a 690ppm equilibrated ice sheet configuration is actually cooler than the simulation with ice surrounding the MDVs, possibly because bedrock elevations in this configuration are slightly higher due to isostatic rebound). We therefore conclude that ice-sheet proximity is not a firstorder influence on temperatures in the MDVs.
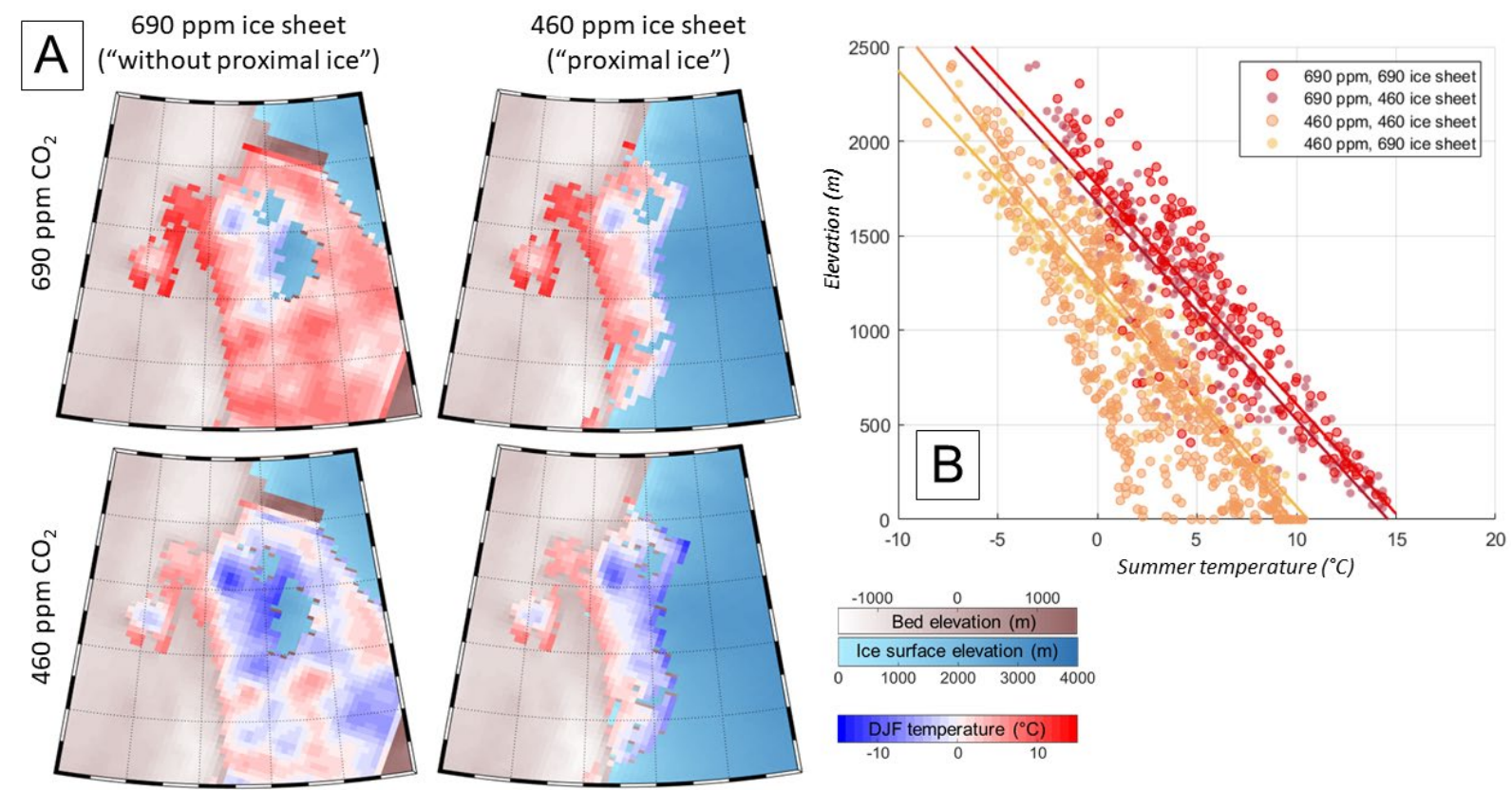

Figure S4. Impact of ice-sheet geometry on MDVs temperature patterns. (A) Modeled summer temperatures under different combinations of $\mathrm{CO}_{2}$ and glacial configuration boundary conditions. Ice is either receded from much of the nearby Transantarctic Mountains ("without proximal ice") or surrounds the MDVs ("with proximal ice"). (B) Summer temperature vs. elevation for ice-free grid cells, with least-squares fit lines shown. For consistency in our comparison, we plot only the grid cells that are ice-free in the 460-ppm ice sheet configuration.

\section{S4. Compilation of MDVs landforms and sedimentary deposits}

Terrestrial geomorphic surveys of the MDVs have been used to categorize unique landscapes into three climatic zones (Marchant and Head, 2007) that capture the large spatial variability in temperature and precipitation influenced by high relief and proximity to the coast (Doran et al., 2002). Proximal to the coast, maximum modern summertime air temperatures and soil temperatures can spike above $0^{\circ} \mathrm{C}$, and high atmospheric moisture and precipitation are sourced from southeasterly winds from the Ross Sea. These conditions result in sufficient meltwater to produce a saturated active upper soil layer promoting landscape evolution and prohibiting the preservation of relict landforms. Temperature and atmospheric moisture generally decrease with distance from the coast as southeasterly winds from the Ross Sea intermix with cool and dry winds flowing off the EAIS. In the Upland Frozen Zone (UFZ), across the highest elevations in the MDVs, mean daily maximum summer air temperatures and soil temperatures 
remain well below freezing with very low atmospheric moisture and lower precipitation (Marchant and Head, 2007).

Here we present a compilation of unique landforms and sedimentary deposits that form and remain intact under UFZ conditions. We surveyed published studies of cold-based drift deposits, sublimation tills, cold-based glaciers, and stable rectilinear ice-cemented slopes (Table $\mathrm{S} 1)$. These specific features were chosen as the most robust indicators for past warming above freezing, given the sensitivity of these landscapes to above-freezing paleotemperatures as well as the likelihood that these landscapes capture warmer environmental conditions in the geomorphic record. The confidence ratings in Fig. 4 and Fig. S5 reflect (a) how sensitive the landscapes are to a specific thermal threshold, (b) whether landscapes evolution is dependent solely on temperature change, and (c) the likelihood that landscapes could record or survive an increased thermal regime.

Sublimation till and sublimation polygons are considered the highest-confidence paleoclimate indicators due to the strong likelihood that warmer environments will be captured and preserved in the geomorphic record. These landforms and sedimentary deposits respond in multiple ways to above-freezing temperatures, some of which are independent of moisture and precipitation. Long-term preservation of sublimation till (and the sublimation polygons that form in the layer of sublimation till) requires preservation of the underlying cold-based ice mass, with mean summer temperature remaining below freezing. Above-freezing temperatures would propagate through the till to the massive buried ice, resulting in secondary ice or evidence for subsurface cold-based ice melting which is not observed (Kowalewski et al., 2011). Additionally, a warmer temperature regime where surface temperatures rise above freezing would result in water percolating into the sand wedge in between the high-centered sublimation polygons (Marchant et al., 2002; Levy et al., 2010). Such a process would be readily apparent in the geomorphic record and result in a composite polygon.

Rectilinear ice cemented slopes have medium paleoclimate confidence: while stability of such slopes reflect persistent dry and sub-zero temperatures, slope failure is highly sensitive to environmental factors such as moisture and precipitation in addition to temperature. Slope failure occurs with increased pore pressure, which is influenced by conditions such as slope angle, soil texture, ice-cement content, and precipitation. Above-freezing temperatures would prompt melting events, which would result in loss of such landscapes (Swanger and Marchant, 2007). We recognize that UFZ features may be found at slightly lower elevations on south-facing slopes compared to north-facing slopes due to differences in insolation (e.g., Swanger and Marchant, 2007).

Cold-based glaciers and cold-based drift are robust modern paleoclimate indicators, but we consider them the lowest-confidence landscapes due to chronological constraints. Age control is limited due to a dearth of sampling and often large errors in cosmogenic dating. As a result, only a minimum age can typically be applied as a cold-based constraint on only a subset of coldbased glaciers. We include them in our analysis because they provide an indication of sub-zero 
temperatures that is independent of precipitation, and the high likelihood that surface meltwater or a transformation to a wet-based regime would be readily captured in the geomorphic record.

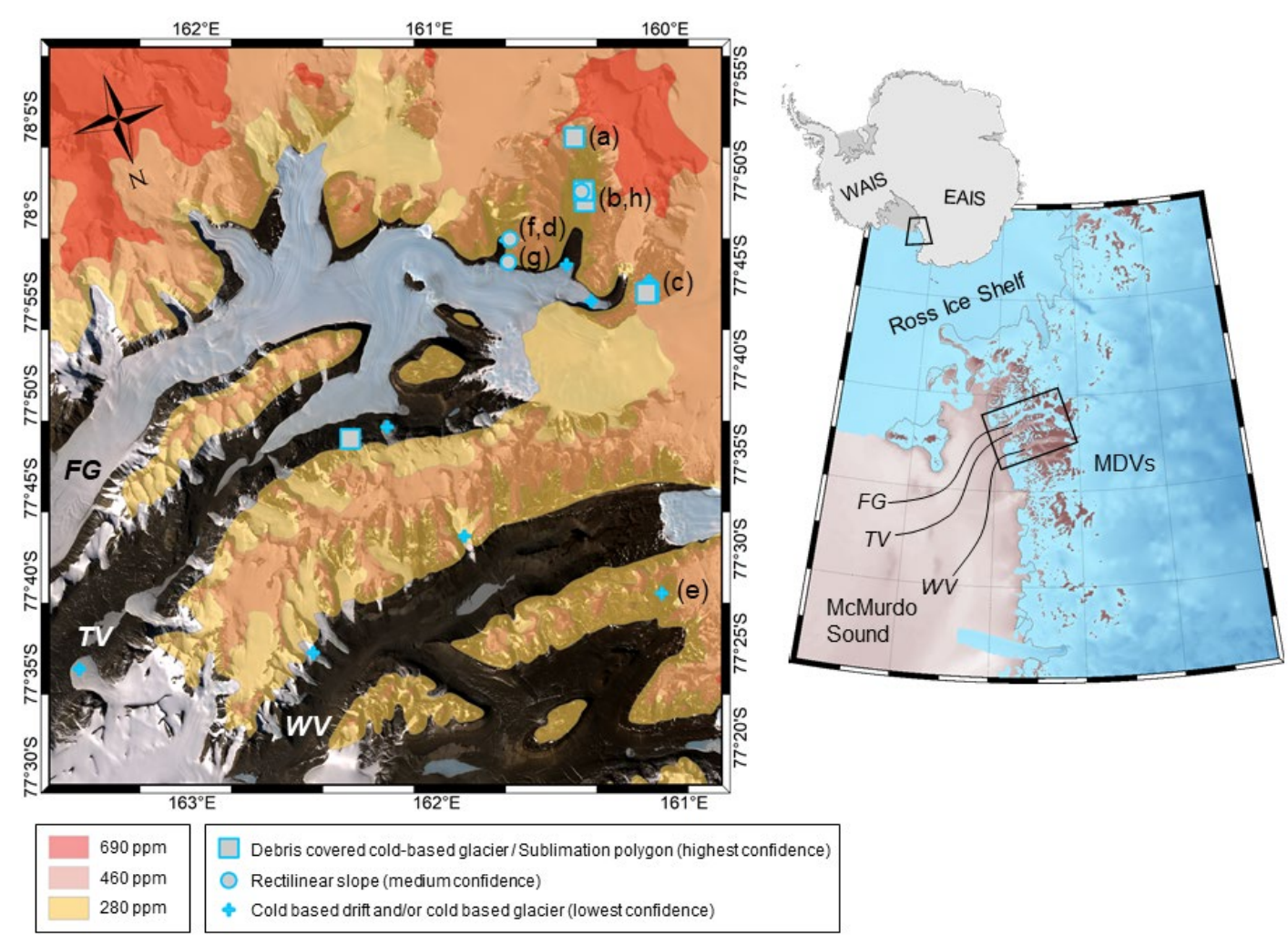

Figure S5. Location of dated landforms and sedimentary deposits with respect to modeled cold zones. Labels a-h correspond to published ages of individual landforms in Figure 1 and listed in Table S1. FG: Ferrar Glacier, TV: Taylor Valley, WV: Wright Valley.

Table S1 includes published ages of these landscapes where available. These dates represent a minimum age of landscape stability: tephrachronology dates ash that has fallen within pre-existing landforms, and cosmogenic ages in these examples represent exposure ages of landscapes and may not account for erosion or shielding. Only landscape ages dated to $>1 \mathrm{Ma}$ are included in Fig. 1 (and Fig. S5) for illustrative purposes. 
Table S1. Compilation of UFZ landforms and sedimentary deposits across the MDVs

\begin{tabular}{|c|c|c|c|c|c|c|}
\hline 莺 & 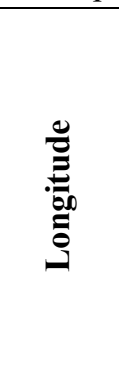 & 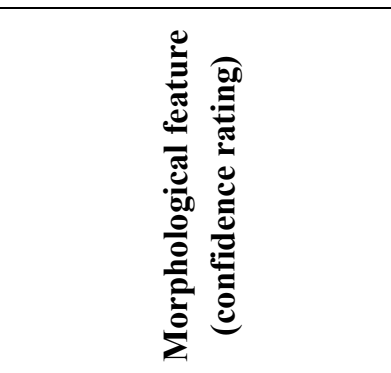 & 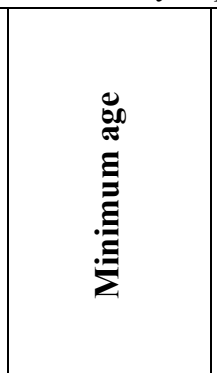 & & 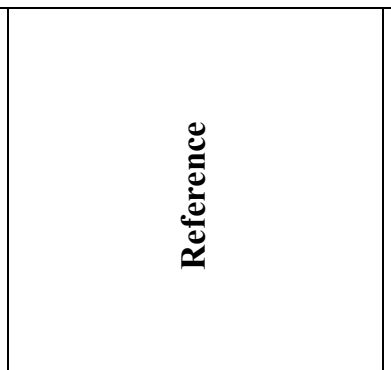 & 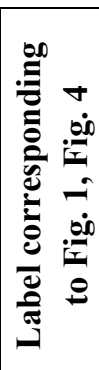 \\
\hline-77.91 & 160.52 & $\begin{array}{l}\text { Debris covered cold-based } \\
\text { glaciers / Sublimation } \\
\text { polygon (1) }\end{array}$ & $2.1 \mathrm{Ma}$ & Friedman Glacier & Shean and Marchant, 2010 & $\mathrm{a}$ \\
\hline-77.85 & 160.57 & $\begin{array}{l}\text { Debris covered cold-based } \\
\text { glaciers / Sublimation } \\
\text { polygon (1) }\end{array}$ & $8.1 \mathrm{Ma}$ & Beacon Valley & Sugden et al., 1995 & $\mathrm{~b}$ \\
\hline-77.75 & 160.44 & $\begin{array}{l}\text { Debris covered cold-based } \\
\text { glaciers / Sublimation } \\
\text { polygon (1) }\end{array}$ & $284+-11 \mathrm{ka}$ & Kennar Valley & Swanger et al., 2017 & \\
\hline-77.71 & 161.89 & $\begin{array}{l}\text { Debris covered cold-based } \\
\text { glaciers / Sublimation } \\
\text { polygon (1) }\end{array}$ & $382+-10 \mathrm{ka}$ & East Stocking & Swanger et al., 2010 & \\
\hline-77.76 & 160.42 & Cold-based drift (3) & $3.1 \mathrm{Ma}$ & Kennar K8 & Swanger et al., 2011 & $\mathrm{c}$ \\
\hline-77.84 & 160.96 & Cold-based drift (3) & $2.2 \mathrm{Ma}$ & Arena Valley & Marchant et al., 1994 & $\mathrm{~d}$ \\
\hline-77.48 & 160.82 & Cold-based drift (3) & $\begin{array}{c}13.52+/-0.09 \\
\mathrm{Ma}\end{array}$ & Circe Rude Valley & Lewis et al., 2007 & $\mathrm{e}$ \\
\hline-77.58 & 163.32 & Cold-based glacier (3) & & $\begin{array}{c}\text { Commonwealth } \\
\text { Glacier }\end{array}$ & Hatton et al., 2020 & \\
\hline-77.53 & 162.33 & Cold-based glacier (3) & & Hart Glacier & Denton et al., 1993 & \\
\hline-77.59 & 161.55 & Cold-based glacier (3) & & West Asgard & Marchant et al., 1993 & \\
\hline-77.71 & 161.72 & Cold-based glacier (3) & & Catspaw Glacier & Swanger et al., 2011 & \\
\hline-77.76 & 160.69 & Cold-based glacier (3) & & Turnabout Glacier & Lewis et al., 2008 & \\
\hline-77.8 & 160.74 & Cold-based glacier (3) & & Taylor Lobe (Beacon) & $\begin{array}{c}\text { Lewis et al., 2008; } \\
\text { Kowalewski et al., } 2012 \\
\end{array}$ & \\
\hline-77.84 & 160.94 & Rectilinear slope (2) & $\begin{array}{c}7.42+/-0.31 \\
\mathrm{Ma}\end{array}$ & Upper Arena & Marchant et al., 1996 & $\mathrm{f}$ \\
\hline-77.82 & 160.98 & Rectilinear slope (2) & $\begin{array}{c}11.28+/-0.05 \\
\mathrm{Ma}\end{array}$ & Lower Arena & Marchant et al., 1996 & $\mathrm{~g}$ \\
\hline-77.86 & 160.57 & Rectilinear slope (2) & $10.66 \mathrm{Ma}$ & Beacon & $\begin{array}{l}\text { Marchant et al., 1996; } \\
\text { Swanger and Marchant, } \\
2007\end{array}$ & $\mathrm{~h}$ \\
\hline
\end{tabular}

\section{S5. Snow accumulation in model simulations}

Landscape preservation in the MDVs precludes glacial advance across this region; therefore, climate model output that satisfies the geologic record should produce minimal snow accumulation to maintain ice-free conditions. Here we support our primary temperature-based analysis with additional investigation of snow depths in our climate model simulations. Figure 
S6 shows seasonal snow depths as they evolve throughout the year across the MDVs under our three $\mathrm{CO}_{2}$ boundary conditions; snow is added as precipitation (snowfall) and removed through ablation (melt, sublimation). In the $280 \mathrm{ppm}$ climate model simulation, snow depths remain below $1 \mathrm{~m}$ across the MDVs uplands in both austral summer and winter (Fig. S6). In the 460 ppm simulation, 1-2 m of winter snowfall accumulates across the MDVs uplands, but is offset by summer ablation (snow depths decrease to below $1 \mathrm{~m}$ during the summer). In the $690 \mathrm{ppm}$ simulation, however, significant snowfall accumulates in winter and snow depths of 1-2 m persist during the summer.
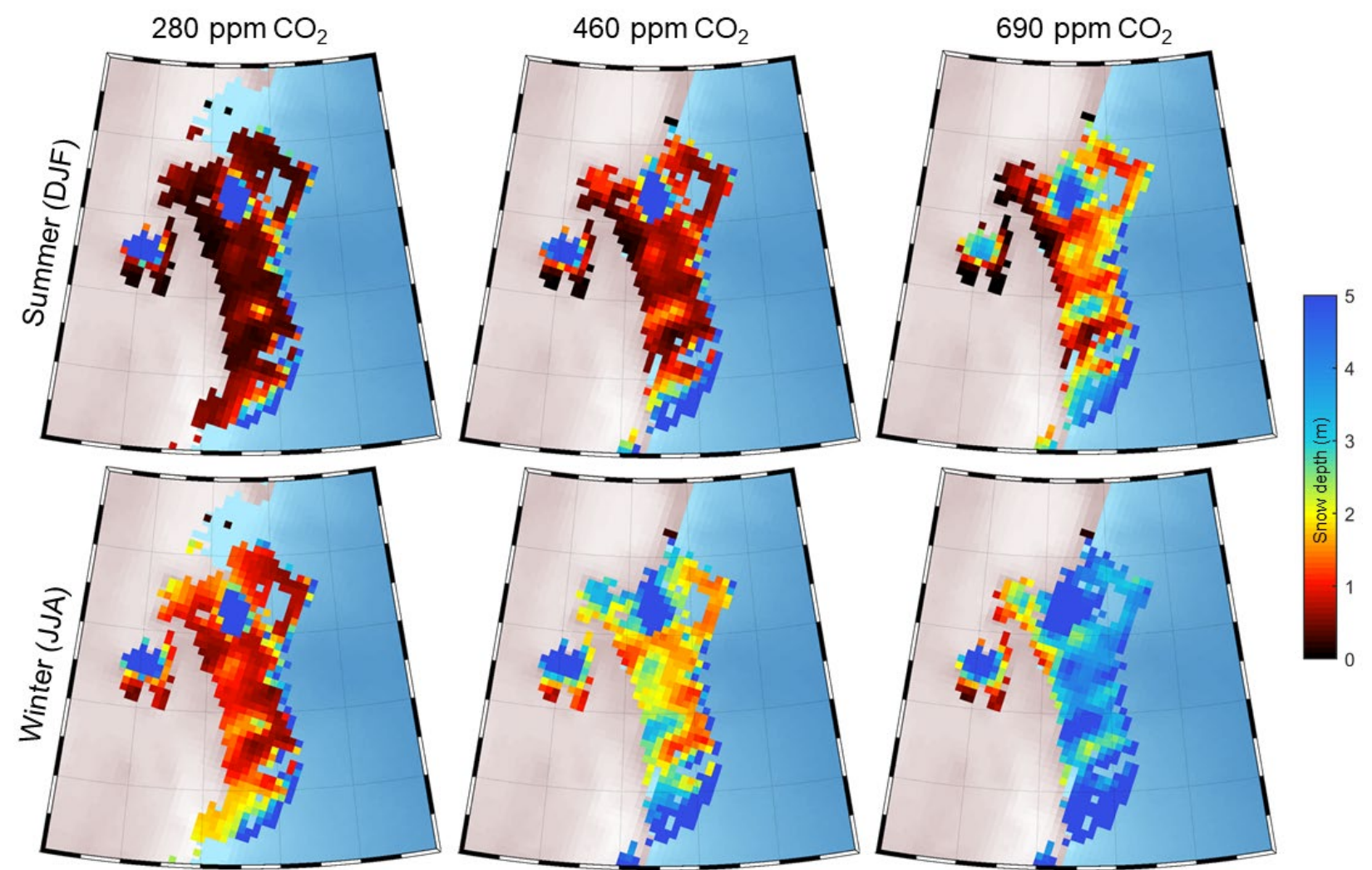

Figure S6. Seasonal snow depths across the MDVs in our (a,b) 280 ppm, (c,d) 460 ppm, and (e,f) 690 ppm climate model simulations.

The distribution of winter snow depths follows precipitation patterns: more snow falls in coastal areas than uplands (Fig. S3c), so winter snow depths are smaller in the high-elevation regions of the MDVs (e.g., see Fig. S6 winter snow depths under $460 \mathrm{ppm} \mathrm{CO}_{2}$ ). During the summer, ablation removes most of the snowpack under 280 and $460 \mathrm{ppm}$ conditions, but snow accumulation in the $690 \mathrm{ppm}$ simulation suggests that glacial advance could have occurred under these past warm conditions and modified the pristine landscapes observed today. This is consistent with our temperature-based observation that the geologic record is consistent with past warm climates under 280 and $460 \mathrm{ppm}$ but not $690 \mathrm{ppm}$.

We note, however, that precipitation model output (and therefore snow accumulation) are less robust climate model metrics than air temperature. Our climate model includes storms, for 
example, which significantly impact precipitation and snow accumulation patterns, but may not be representative of long-term climate. This precipitation variability is evident in multi-model intercomparison projects, where precipitation across different climate models produces a much larger spread than temperature output (e.g., Tang et al., 2018; Barthel et al., 2020; Nowicki et al., 2020). Here we average 10 years of climate model output, which smooths some of this variability but not all; longer simulations would produce less variable precipitation and accumulation patterns but are computationally prohibitive. 


\section{SUPPLEMENTAL REFERENCES}

Alder, J.R., Hostetler, S.W., Pollard, D., and Schmittner, A., 2011, Evaluation of a present-day climate simulation with a new coupled atmosphere-ocean model GENMOM: Geoscientific Model Development, v. 4, p. 69-83, doi:10.5194/gmd-4-69-2011.

Austermann, J., Pollard, D., Mitrovica, J.X., Moucha, R., Forte, A.M., DeConto, R.M., Rowley, D.B., and Raymo, M.E., 2015, The impact of dynamic topography change on antarctic ice sheet stability during the mid-pliocene warm period: Geology, v. 43, p. 927-930, doi:10.1130/G36988.1.

Badger, M.P.S., Chalk, T.B., Foster, G.L., Bown, P.R., Gibbs, S.J., Sexton, P.F., Schmidt, D.N., Pälike, H., Mackensen, A., and Pancost, R.D., 2019, Insensitivity of alkenone carbon isotopes to atmospheric $\mathrm{CO} 2$ at low to moderate $\mathrm{CO} 2$ levels: Climate of the Past, v. 15, p. 539-554, doi:10.5194/cp-15-539-2019.

Barthel, A., Agosta, C., Little, C.M., Hattermann, T., Jourdain, N.C., and Goelzer, H., 2020, CMIP5 model selection for ISMIP6 ice sheet model forcing: Greenland and Antarctica: The Cryosphere, v. 14, p. 855-879, doi:10.5194/tc-14-855-2020.

DeConto, R.M., Pollard, D., and Kowalewski, D., 2012, Modeling Antarctic ice sheet and climate variations during Marine Isotope Stage 31: Global and Planetary Change, v. 88-89, p. 45-52, doi:10.1016/j.gloplacha.2012.05.018.

Denton, G.H., Sugden, D.E., Marchant, D.R., Hall, B.L., and Wilch, T.I., 1993, East Antarctic ice sheet sensitivity to Pliocene climatic change from a dry valleys perspective: Geografiska Annaler, Series A, v. 75 A, p. 155-204, doi:10.1080/04353676.1993.11880393.

Doran, P.T., and Fountain, A.G., 2021a, Beacon Valley Meteorological Station Measurements: Environmental Data Initiative, https://doi.org/10.6073/pasta/8f167e709326e9b9ad50f586e20da575 (accessed 30 January 2021).

Doran, P.T., Fountain, A.G., 2021b, High frequency measurements from Canada Glacier Meteorological Station (CAAM), McMurdo Dry Valleys, Antarctica (1994-2019, ongoing): Environmental Data Initiative, https://doi.org/10.6073/pasta/c9d8abda35da726a855676696426f4a0 (accessed 30 January 2021).

Doran, P.T., and Fountain, A.G., 2021c, High frequency measurements from Commonwealth Glacier Meteorological Station (COHM), McMurdo Dry Valleys, Antarctica (1993-2019, ongoing): Environmental Data Initiative, https://doi.org/10.6073/pasta/f2a94323c25d62d3266b37c48f420990 (accessed 30 January 2021).

Doran, P.T., and Fountain, A.G., 2021d, High frequency measurements from Explorers Cove Meteorological Station (EXEM), McMurdo Dry Valleys, Antarctica (1995-2020, ongoing): Environmental Data Initiative, 
https://doi.org/10.6073/pasta/8d8862ef0930647a021 cf8fc3e25f307 (accessed 30 January 2021).

Doran, P.T., and Fountain, A.G., 2021e, High frequency measurements from Friis Hills Meteorological Station (FRSM), McMurdo Dry Valleys, Antarctica (2010-2019, ongoing): Environmental Data Initiative, https://doi.org/10.6073/pasta/2a1aa951d8008192bbc579082eab78ad (accessed 30 January 2021).

Doran, P.T., and Fountain, A.G., 2021f, High frequency measurements from Howard Glacier Meteorological Station (HODM), McMurdo Dry Valleys, Antarctica (1993-2019, ongoing): Environmental Data Initiative, https://doi.org/10.6073/pasta/59e4eb25b7f4b70c09333401e3bca980 (accessed 30 January 2021).

Doran, P.T., and Fountain, A.G., 2021g, High frequency measurements from Lake Bonney Meteorological Station (BOYM), McMurdo Dry Valleys, Antarctica (1993-2019, ongoing): Environmental Data Initiative, https://doi.org/10.6073/pasta/fdeac0049adcdb2be227bef128cdea52 (accessed 30 January 2021).

Doran, P.T., and Fountain, A.G., 2021h, High frequency measurements from Lake Brownworth Meteorological Station (BRHM), McMurdo Dry Valleys, Antarctica (1994-2019, ongoing): Environmental Data Initiative, https://doi.org/10.6073/pasta/efe4c3aeafcd8fb311a299df2f9d551a (accessed 30 January 2021).

Doran, P.T., and Fountain, A.G., 2021i, High frequency measurements from Lake Fryxell Meteorological Station (FRLM), McMurdo Dry Valleys, Antarctica (1993-2019, ongoing): Environmental Data Initiative, https://doi.org/10.6073/pasta/f76000427015642ded094d19c91b4de2 (accessed 30 January 2021).

Doran, P.T., and Fountain, A.G., 2021j, High frequency measurements from Lake Hoare Meteorological Station (HOEM), McMurdo Dry Valleys, Antarctica (1987-2019, ongoing): Environmental Data Initiative, https://doi.org/10.6073/pasta/a3028beec54a2f6f8266cd030bb88662 (accessed 30 January 2021).

Doran, P.T., and Fountain, A.G., 2021k, High frequency measurements from Lake Vanda Meteorological Station (VAAM), McMurdo Dry Valleys, Antarctica (1994-2019, ongoing): Environmental Data Initiative, https://doi.org/10.6073/pasta/fe69ed49222efa29539b02f6b50c9b3d (accessed 30 January 2021).

Doran, P.T., and Fountain, A.G., 20211, High frequency measurements from Lake Vida Meteorological Station (VIAM), McMurdo Dry Valleys, Antarctica (1995-2019, ongoing): Environmental Data Initiative, 
https://doi.org/10.6073/pasta/62c6d8ef4f9b9157c1f619dfe798ab8d (accessed 30 January 2021).

Doran, P.T., and Fountain, A.G., 2021m, High frequency measurements from Miers Valley Meteorological Station (MISM), McMurdo Dry Valleys, Antarctica (2012-2019, ongoing): Environmental Data Initiative, https://doi.org/10.6073/pasta/65e5a3439ce3a5150f3edaaf71fe596c (accessed 30 January 2021).

Doran, P.T., and Fountain, A.G., 2021n, High frequency measurements from Mount Fleming Meteorological Station (FLMM), McMurdo Dry Valleys, Antarctica (2011-2019, ongoing): Environmental Data Initiative, https://doi.org/10.6073/pasta/bff5a2edce0bc3d4a1978eec38ceee64 (accessed 30 January 2021).

Doran, P.T., and Fountain, A.G., 2021o, High frequency measurements from Taylor Glacier Meteorological Station (TARM), McMurdo Dry Valleys, Antarctica (1994-2019, ongoing): Environmental Data Initiative, https://doi.org/10.6073/pasta/75716cc6dde2fc132997953fde1b4448 (accessed 30 January 2021).

Doran, P.T., and Fountain, A.G., 2021p, F6 Snowfence Station Measurements: Environmental Data Initiative, https://doi.org/10.6073/pasta/8895c6240d04249eb5acb4f2d979987a (accessed 30 January 2021).

Doran, P.T., McKay, C.P., Clow, G.D., Dana, G.L., Fountain, A.G., Nylen, T., and Lyons, W.B., 2002, Valley floor climate observations from the McMurdo dry valleys, Antarctica, 19862000: Journal of Geophysical Research Atmospheres, v. 107, p. 1-12, doi:10.1029/2001JD002045.

Halberstadt, A.R.W., Chorley, H., Levy, R.H., Naish, T., Deconto, R.M., Gasson, E., and Kowalewski, D.E., 2021, CO2 and tectonic controls on Antarctic climate and ice-sheet evolution in the mid-Miocene: Earth and Planetary Science Letters, v. 564, p. 116908 , doi:10.1016/j.eps1.2021.116908.

Hatton, J.E. et al., 2020, Silicon Isotopic Composition of Dry and Wet-Based Glaciers in Antarctica: Frontiers in Earth Science, v. 8, doi:10.3389/feart.2020.00286.

Kowalewski, D.E., Marchant, D.R., Head, J.W., and Jackson, D.W., 2012, A 2D Model for Characterising First-order Variability in Sublimation of Buried Glacier Ice, Antarctica: Assessing the Influence of Polygon Troughs, Desert Pavements and Shallow Subsurface Salts: Permafrost and Periglacial Processes, v. 23, p. 1-14, doi:10.1002/ppp.731.

Kowalewski, D.E., Marchant, D.R., Swanger, K.M., and Head, J.W., 2011, Modeling vapor diffusion within cold and dry supraglacial tills of Antarctica: Implications for the preservation of ancient ice: Geomorphology, v. 126, p. 159-173, doi:10.1016/j.geomorph.2010.11.001.

Levy, J.S., Fountain, A.G., Head, J.W., and Marchant, D.R., 2010, Physical Controls on Antarctic Dry Valleys Permafrost Geomorphology and Soil Ecosystem Habitability: Cold- 
Desert Processes and Mars Astrobiological Implications, in Astrobiology Science Conference, April, Lunar Planetary Institute, p. 5060, https://ui.adsabs.harvard.edu/abs/2010LPI....41.1055L/abstract.

Lewis, A.R. et al., 2008, Mid-Miocene cooling and the extinction of tundra in continental Antarctica.: Proceedings of the National Academy of Sciences of the United States of America, v. 105, p. 10676-10680, doi:10.1073/pnas.0802501105.

Lewis, A.R., Marchant, D.R., Ashworth, A.C., Hemming, S.R., and Machlus, M.L., 2007, Major middle Miocene global climate change: Evidence from East Antarctica and the Transantarctic Mountains: Geological Society of America Bulletin, v. 119, p. 1449, doi:10.1130/B26134.

Marchant, D.R., Denton, G.H., Bockheim, J.G., Wilson, S.C., and Kerr, A.R., 1994, Quaternary changes in level of the upper Taylor Glacier, Antarctica: implications for paleoclimate and East Antarctic Ice Sheet dynamics: Boreas, v. 23, p. 29-43, doi:https://doi.org/10.1111/j.1502-3885.1994.tb00583.x.

Marchant, D.R., Denton, G.H., Sugden, D.E., and Swisher, C.C., 1993, Miocene glacial stratigraphy and landscape evolution of the western Asgard Range, Antarctica: Geografiska Annaler, Series A, v. 75 A, p. 303-330, doi:10.1080/04353676.1993.11880398.

Marchant, D.R., Denton, G.H., Swisher, C.C., and Potter, N., 1996, Late Cenozoic Antarctic paleoclimate reconstructed from volcanic ashes in the Dry Valleys region of southern Victoria Land: Bulletin of the Geological Society of America, v. 108, p. 181-194, doi:10.1130/0016-7606(1996)108<0181:LCAPRF>2.3.CO;2.

Marchant, D.R., and Head, J.W., 2007, Antarctic dry valleys: Microclimate zonation, variable geomorphic processes, and implications for assessing climate change on Mars: Icarus, v. 192, p. 187-222, doi:10.1016/j.icarus.2007.06.018.

Marchant, D.R., Lewis, A.R., Phillips, W.M., Moore, E.J., Souchez, R.A., Denton, G.H., Sugden, D.E., Potter, J., and Landis, G.P., 2002, Formation of patterned ground and sublimation till over Miocene glacier ice in Beacon Valley, southern Victoria Land, Antarctica: Bulletin of the Geological Society of America, v. 114, p. 718-730, doi:10.1130/0016-7606(2002)114<0718:FOPGAS>2.0.CO;2.

Martínez-Botí, M.A., Foster, G.L., Chalk, T.B., Rohling, E.J., Sexton, P.F., Lunt, D.J., Pancost, R.D., Badger, M.P.S., and Schmidt, D.N., 2015, Plio-Pleistocene climate sensitivity evaluated using high-resolution CO2 records: Nature, v. 518, doi:10.1038/nature14145.

Miller, S.R., Fitzgerald, P.G., and Baldwin, S.L., 2010, Cenozoic range-front faulting and development of the Transantarctic Mountains near Cape Surprise, Antarctica: Thermochronologic and geomorphologic constraints: Tectonics, v. 29, p. 1-21, doi:10.1029/2009TC002457.

Nowicki, S. et al., 2020, Experimental protocol for sea level projections from ISMIP6 standalone ice sheet models: Cryosphere, v. 14, p. 2331-2368, doi:10.5194/tc-14-2331-2020. 
Nylen, T.H., Fountain, A.G., and Doran, P.T., 2004, Climatology of katabatic winds in the McMurdo dry valleys, southern Victoria Land, Antarctica: Journal of Geophysical Research: Atmospheres, v. 109, p. 1-9, doi:10.1029/2003jd003937.

Obryk, M.K., Doran, P.T., Fountain, A.G., Myers, M., and McKay, C.P., 2020, Climate From the McMurdo Dry Valleys, Antarctica, 1986-2017: Surface Air Temperature Trends and Redefined Summer Season: Journal of Geophysical Research: Atmospheres, v. 125, doi:10.1029/2019JD032180.

Pagani, M., Liu, Z., Lariviere, J., and Ravelo, A.C., 2010, High Earth-system climate sensitivity determined from Pliocene carbon dioxide concentrations: Nature Geoscience, v. 3, p. $27-$ 30, doi:10.1038/ngeo724.

Pal, J.S. et al., 2007, Regional climate modeling for the developing world: the ICTP RegCM3 and RegCNET: Bulletin of the American Meteorological Society, v. 88, p. 1395-1410.

Paxman, G.J.G., Jamieson, S.S.R., Hochmuth, K., Gohl, K., Bentley, M.J., Leitchenkov, G., and Ferraccioli, F., 2019, Reconstructions of Antarctic topography since the Eocene-Oligocene boundary: Palaeogeography, Palaeoclimatology, Palaeoecology, v. 535, p. 109346, doi:10.1016/j.palaeo.2019.109346.

Pollard, D., and DeConto, R.M., 2012, Description of a hybrid ice sheet-shelf model, and application to Antarctica: Geoscientific Model Development, v. 5, p. 1273-1295, doi:10.5194/gmd-5-1273-2012.

Rae, J.W.B., Zhang, Y.G., Liu, X., Foster, G.L., Stoll, H.M., and Whiteford, R.D.M., 2021, Atmospheric cobinf2einf over the past 66 million years from marine archives: Annual Review of Earth and Planetary Sciences, v. 49, p. 609-641, doi:10.1146/annurev-earth082420-063026.

Seki, O., Foster, G.L., Schmidt, D.N., Mackensen, A., Kawamura, K., and Pancost, R.D., 2010, Alkenone and boron-based Pliocene pCO2 records: Earth and Planetary Science Letters, v. 292, p. 201-211, doi:10.1016/j.eps1.2010.01.037.

Shean, D.E., and Marchant, D.R., 2010, Seismic and GPR surveys of Mullins Glacier, McMurdo Dry Valleys, Antarctica: Ice thickness, internal structure and implications for surface ridge formation: Journal of Glaciology, v. 56, p. 48-64, doi:10.3189/002214310791190901.

Stoll, H.M., Guitian, J., Hernandez-Almeida, I., Mejia, L.M., Phelps, S., Polissar, P., Rosenthal, Y., Zhang, H., and Ziveri, P., 2019, Upregulation of phytoplankton carbon concentrating mechanisms during low CO 2 glacial periods and implications for the phytoplankton pCO 2 proxy: Quaternary Science Reviews, v. 208, p. 1-20, doi:10.1016/j.quascirev.2019.01.012.

Sugden, D.E., Marchant, D.R., Potter, N., Souchez, R.A., Denton, G.H., Swisher, C.C., and Tison, J.-L., 1995, Preservation of Miocene Glacier Ice in East Antarctica: Nature, v. 376, p. 412-414, doi:10.1038/376412a0.

Swanger, K.M., Lamp, J.L., Winckler, G., Schaefer, J.M., and Marchant, D.R., 2017, Glacier advance during Marine Isotope Stage 11 in the McMurdo Dry Valleys of Antarctica: Scientific Reports, v. 7, p. 41433, doi:10.1038/srep41433. 
Swanger, K.M., and Marchant, D.R., 2007, Sensitivity of ice-cemented Antarctic soils to greenhouse-induced thawing: Are terrestrial archives at risk? Earth and Planetary Science Letters, v. 259, p. 347-359, doi:10.1016/j.epsl.2007.04.046.

Swanger, K.M., Marchant, D.R., Kowalewski, D.E., and Head, J.W., 2010, Viscous flow lobes in central Taylor Valley, Antarctica: Origin as remnant buried glacial ice: Geomorphology, v. 120, p. 174-185, doi:10.1016/j.geomorph.2010.03.024.

Swanger, K.M., Marchant, D.R., Schaefer, J.M., Winckler, G., and Head, J.W., 2011, Elevated East Antarctic outlet glaciers during warmer-than-present climates in southern Victoria Land: Global and Planetary Change, v. 79, p. 61-72, doi:10.1016/j.gloplacha.2011.07.012.

Tang, M.S.Y., Chenoli, S.N., Samah, A.A., and Hai, O.S., 2018, An assessment of historical Antarctic precipitation and temperature trend using CMIP5 models and reanalysis datasets: Polar Science, v. 15, p. 1-12, doi:10.1016/j.polar.2018.01.001.

Webb, P.N., 1974, Micropaleontology, paleoecology and correlation of the Pecten Gravels, Wright Valley, Antarctica, and description of Trochoelphidiella onyxi n. gen., n. sp.: The Journal of Foraminiferal Research, v. 4, p. 185-199. 